\title{
Manchar Lake's Hypothetical Restoration and Willingness of Fishing Communities to Switch Back To Fishing
}

\author{
Muhammad Azeem $^{1 a}$, Junaid Alam Memon ${ }^{1 b}$, Fateh Muhammad Mari² \\ RECEIVED ON 25.03.2019, ACCEPTED ON 26.07.2019
}

\begin{abstract}
Environmental and anthropogenic changes in lakes have implications for fishers' livelihoods in form of their forced migration and occupational change. Those advocating lake restorations often face a dilemma when asked if lake restoration will also restore the lost livelihoods. Answering such questions are difficult because most people are not programmed for frequent changes in their livelihood structures. Using the case study of Manchar Lake fishers who seemingly have faced such transition, this study brings insights on this broad question. We developed an in-person survey based on Contingent Valuation Method (CVM) to study 300 fishers' responses to a hypothetical situation whereby they were asked to "Switch Back" to Manchar Lake assuming that it has been restored to provide various ecosystem services. Results show that complete transformation in the livelihoods of fishing communities has taken place with remarkable variation in their access to assets and livelihood outcomes. Despite increase in their access to physical capital such as school, hospital, roads, and markets, the communities are still vulnerable to income shocks and rarely enjoy privileges such as house ownership. The comparative state of current and past livelihoods and asset possessions determine ones' willingness to switch back to fishing in Manchar Lake. Those who may have performed better in the said transition are less likely to return to their erstwhile occupations even if the lake is restored and vice-versa. We conclude that satisfaction with current livelihood outcomes is low and willingness to switch back to fishing in Manchar Lake is high since many had been poor performers in the transition. While the environmental rationale for the Manchar Lake's ecological restoration already exists, this study suggests that there also exists a socioeconomic rationale albeit in a way that restoration also supports contemporary ecological services such as tourism.
\end{abstract}

Keywords: Migration, Lake Restoration, Ecosystem, Fishers, Manchar Lake, CVM

\section{INTRODUCTION}

Ecosystem services provide basis to link human and natural systems. The main idea underlying this concept is that changes in natural systems affect human well-being and vice versa [1]. Literature on ecosystem services suggests that biological services are identified and actually recognized by society only when they are degraded [2]. Concerns over resource degradation and loss of ecosystem had been the fundamental motivation behind investment in establishing institutional arrangements for sustainable management of critical natural resource systems [3].

Providing a historical perspective, the Millennium Ecosystem Assessment Report (2005) reported a loss of more than $50 \%$ wetland area during the 20th century. It is noted however that extrapolating this rate of loss to other regions or wetland types was "speculative only." For example, the global wetlands ranges between $30 \%$ and $90 \%$, depending on the

\footnotetext{
${ }^{1}$ Pakistan Institute of Development Economics, Islamabad.

E-mail: ${ }^{a}$ qureshiazeem1@gmail.com (Corresponding Author), bjunaid.alam@alumni.ait.asia

${ }^{2}$ Planning and Development Department, Government of Sindh, Karachi. Email: fateh.marri@gmail.com

This is an open access article published by Mehran University of Engineering and Technology, Jamshoro under CC BY 4.0 International License.
} 
region under consideration [4]. The earlier global review by Davidson [5] suggests that the wetland loss could be as high as $87 \%$, while the $20^{\text {th }}$ century losses alone may range between $64 \%$ and $71 \%$.

Lakes normally show a general impression of relative calmness and stability concerning the set of natural resources they harbor [6]. Freshwater ecosystem systems give an extensive variety of environmental services, yet changes in land use in populated regions have had disproportionately huge negative impact on lakes' natural health and functioning [7].

Among the major worldwide ecological changes that we have seen so far the lakes are dying more frequently than any other resource system [8]. Various studies have expressed that the reduction of lakes, shape the prosperity and security of lake inhabitants [9]. With a few special cases, investigations rarely analyze the various components through which lake fluctuations affected livelihood. Also, less is known about the scope of chances for locals who can access under lake-level fluctuations-including where lake contamination fits in the suite of stressors influencing family unit occupations [10]. Concerning the rapid degradation and disappearance of lakes all around, the interest in their restoration is emerging. Over the last 50 years, numerous lakes have been restored and different techniques have been developed, tested and adopted all around the world [11].

The optimism with lake restoration however is not substantiated with empirical evidence that the restored lakes conserve regional biodiversity and recreate efficient ecological systems with all associated social, economic, and environmental benefits [12]. There are just a few pieces of evidence that created or restored wetlands can function and behave like natural ones [13]. These evidences too are mainly concentrated towards the assessment of environmental and ecological aspects of restoration. In many cases, scientific knowledge is unavailable to know if the lake restoration also restores local livelihoods [12]. So, after restoring the lake, no one is sure that previous activities of local livelihood can reasonably be restored.

This poses a serious challenge to the lake restoration proposals and accordingly benefiting all users, particularly the poor people whose jobs are excessively reliant on lakes. Akele [14] noted that while restoration projects expected to enhance habitat conditions are supposed to positively impact fishing groups and fish resources at wider scales [15]. The effects on fish groups during lake restoration lakes have yet to be estimated. A key requirement for future lake habitat restoration extends through which we can compare alternative restoration approaches and local livelihood with expected quantitative outcomes [16].

What is often presupposed is that population depending on lakes and wetlands before their intolerable levels of degradation are hapless, sitting idle and waiting for the time when they can restart their livelihood activities. This may be true in some cases and to some extent, but it is more likely that many of those may have changed the livelihood activities, adopted a new set of skills, and most probably shifted to other occupations either at the same place or had migrated elsewhere. For example, [17] showed that loss of livelihood of erstwhile camel herders turned them into fishers in the Indus Delta. It makes more sense as people cannot just sit idle and die silently. They must see around for other available options. Lakes also degrade gradually thus giving people time and motivation to shift their livelihoods. In that case, if even the lake is fully restored with all associated socioeconomic benefits, those who may have changed their livelihood or shifted to other places may not be willing to return and revert their livelihood on past patterns. People are generally not programmed to taking frequent risks associated with livelihood transitions and lifestyle changes and try their best to maintain status quo. New entrants may also face similar dilemma and feel hesitant to get benefit from the enhanced livelihood opportunities offered by the restored lakes because of the lack of required skill set and apprehensions of being worse-off.

Thus, it is plausible to assume that even if ecologically restored, some lakes may not trigger similar scales of social activates and thereby continue to underperform and eventually die because humans are also important elements of ecosystem health. Japanese Satoyama Initiative builds on the principle that humans and ecosystems cannot function in isolation from each other and have a complementary symbiosis that must 
be integrated into any ecosystem initiative [18]. Thus, before initiating any activity, it is important to assess the human factors if the objective is to have a fully functioning ecosystem. There are very few studies that have addressed this issue and those of available too are focused on the other ecosystems and virtually none addressing the lake restoration in developing or developed worlds.

Using the case study of Manchar Lake fishers who seemingly have faced such transition, this study brings insights on this broad question. It will address this paucity of insights needed for better understanding of ecological restoration of lakes in Pakistan with broader implications for both developed and developing countries' future lake restoration initiatives.

\section{METHODOLOGY}

\subsection{The Concept and Data}

Previous research regarding lake restoration has largely focused on the restoring lake ecosystem without much understanding of its impact on local livelihoods. To get better knowledge on restoring the lake-dependent livelihoods, we designed in-depth interviews from members of fishing communities of Manchar Lake (the largest lake in Pakistan) who had migrated and shifted to other professions. The interviews focused on hypothetical questions from fishing communities to know their views if the Manchar Lake is restored.

In economic rationale, fishers are likely to shift back to fishing when they perceive that their net benefits are higher than what they are currently earning. However, fishers' profile characteristics (education, age, household size, skillsets etc.,) may influence their decision making. These factors are knotted and collectively determine what benefits a fisher may reasonably reap from the Manchar Lake restoration. Add-in is the set of other influences such as institutional factors and level of benefits together with the existing conditions of Manchar Lake influence the fishers' decision (willingness) to switch back to fishing. Thus, subject to resource, technical, personal, and skills constraints, fishers select from the alternative opportunities that fit their circumstances and account for, both the net returns and risk.

We will focus on respondents' preferences about the benefits provided by the lake restoration, their perceptions, and their current condition about switching back. The extracted factors are organized into three categories: household demographic, old benefits provided by the lake, and new benefits to be provided by the lake. Household demographic variables include gender, age, educational background, occupation, and income. Old benefits include traditional fishing, spiritual value, aesthetics, and cultural values. New benefit variables included tourism and its allied activities such as boating, water sports, fishing, hoteling.

A structured questionnaire was used to collect the information. It contained both close- and open-ended questions and reflected various levels of measurement. To answer the research questions, there was a need to collect information on fisher's preferences. The method, as literature suggests [19], has allowed us to gather data from a large number of fishers.

A total sample size of 300 fishers was determined. Since the loss of lake dependent livelihoods caused fisher to migrate here and there, their actual whereabouts were to be traced. Resultantly the snowball technique was applied in this study, to identify and track respondents who switched to different occupations in different areas. The aim was to make the findings more illustrative. The fishers from Manchar Lake shifted to other occupations or migrated to other areas for the new professions were selected. The indices were calculated by using an methodology developed by Miah [20] and for the calculation of numerical variables equation developed by CBS [21] . Further, both methods were also used by Sharma [22], Mahdi [23] and others.

Adopting the Holden and Shiferaw [24] approach, Willingness to pay (WTA) was modeled to inquire the preferences. To answer the question a Contingent Valuation (CV) study was done. CV method has been widely used to show the "economic value" of ecological goods and services. The term 'economic value' is very much characterized in the standard 
economic theory, which is the estimation of changes in the well-being of people. For these goods and services, this study made a hypothetical situation of new and old benefits of the lake to estimate the fishers' willingness to switch back (WTSB) under two scenarios: old traditional benefits and under new benefits.

\subsection{Model Specification}

Considering how different factors might affect Willingness To Switch Back (WTSB), the model has been specified. The dependent variable WTSB is dummy ( 1 for Yes 0 for No). It is regressed on a different set of independent variables. To capture the relationship of WTSB with different variables, the model included dependent variables as listed and described in Table 1.
Since the dependent variable is dummy, so the logit regression model was used to analyze the relation of independent variables with dependent variables. This model was adopted from [28]. The equation form of the model is:

$$
\begin{aligned}
& \text { WTSB }=\beta 0+\beta 1(\mathrm{EDU})+\beta 2(\mathrm{HHsize})+\beta 3(\mathrm{AGE}) \\
& \beta 4(\mathrm{AGESq})+\beta 5(\mathrm{SA})+\beta 6(\mathrm{JQ})+\beta 7(\mathrm{MT})+\beta 8 \\
& (\mathrm{PM})+\beta 9(\mathrm{Fc})+\beta 10(\mathrm{AM})+\beta 11(\mathrm{TC})+\mu \mathrm{i}
\end{aligned}
$$

where

$\beta 0$ is the intercept and $\beta 1$ is the slope

$\mathrm{EDU}=$ Education of the respondent

$\mathrm{AGE}=$ Age in years

$\mathrm{S}=$ Skill Level

MT $=$ Migration Time

\begin{tabular}{|c|c|c|}
\hline \multicolumn{3}{|c|}{ Table 1: Variables of the Study } \\
\hline Variables & Unit & Description and Level of Measurement (see [25]) \\
\hline Household size & No. of Persons & $\begin{array}{l}\text { Measured as continuous variable (interval and ratio). Household } \\
\text { size is taken as the total number of family members who share the } \\
\text { kitchen. }\end{array}$ \\
\hline Age & Years & $\begin{array}{l}\text { Age is also measured as a continuous variable. Age is taken as } \\
\text { number of completed years since birth. }\end{array}$ \\
\hline Age Square & Sq Years & This variable is square of the Age variable. \\
\hline Skill level & Likert Scale & $\begin{array}{l}\text { Those respondents who have switched to other occupation was } \\
\text { asked what level they have skills of current occupation beside } \\
\text { fishery. The fishers who will be able to adopt a new skill, training, } \\
\text { and say very low, low, average, high, and very high. }\end{array}$ \\
\hline Education & Years & $\begin{array}{l}\text { This variable is a continuous variable taken as competed years of } \\
\text { schooling. }\end{array}$ \\
\hline Job quality & $\begin{array}{l}\text { Composite } \\
\text { Index }\end{array}$ & $\begin{array}{l}\text { it's a composite of sub-indexes namely job security, health security, } \\
\text { social prestige, income, and working hours. The concept is } \\
\text { borrowed. See: [26]. }\end{array}$ \\
\hline Migration Time & Years & $\begin{array}{l}\text { It is the number of years since the fishers had migrated from } \\
\text { Manchar Lake to the nearby town. }\end{array}$ \\
\hline Partially Migrated & Dummy & $\begin{array}{l}\text { It is the dummy variable of those fishers who are partially migrated } \\
\text { to the nearby towns. } 1 \text { for partially migrated } 0 \text { for fully migrated. }\end{array}$ \\
\hline $\begin{array}{l}\text { Attachment to } \\
\text { Manchar Lake }\end{array}$ & Index & $\begin{array}{l}\text { This variable consists of cultural values, aesthetic Values, spiritual } \\
\text { values, and the environment. The concept is borrowed. See: [27] }\end{array}$ \\
\hline Difference of facilities & Index & $\begin{array}{l}\text { This variable is the difference of current and previous distance from } \\
\text { house to job, health, education, road and market facilities. }\end{array}$ \\
\hline Total cost & Rupees & $\begin{array}{l}\text { It is the cost that fishers bear while traveling from home to job. The } \\
\text { total cost was calculated as first we find opportunity cost which is } \\
\text { (time } x 2 \text { ) x wage rate then for total cost we have summed the } \\
\text { opportunity cost and travel cost. }\end{array}$ \\
\hline
\end{tabular}

$\mathrm{Fc}=\mathrm{F}$

$\mathrm{TC}=$ Total Cost 
WTSB $=$ Willingness to Switch Back

HHS $=$ Household Size

AGESq $=$ Age Square

JQ = Job Quality

$\mathrm{PM}=$ Partially Migrated

$\mathrm{AM}=$ Attachment to Mancher Lake

\section{RESULTS AND DISCUSSION}

\subsection{Descriptive Analysis}

\section{Cultural landscape and settings of Manchar Lake}

Manchar Lake is situated on west of the Indus River in the Sindh province, as shown in Fig. 1. It is Pakistan's largest shallow freshwater and one of Asia's biggest lakes [29]. Located at $18 \mathrm{~km}$ in the west of Sehwan city, the lake is encompassed by the Laki Mountain in the south, the Kirthar Mountain in the west, and the River Indus in the east. Its mean profundity ranges between 2.5 and 3.75 meters and it covers a region of $233 \mathrm{~km}^{2}$ [30]. Additionally, it is also a water reservoir that is nourished by the Aral and Danister channels from the River Indus, mountains downpours, and the Main Nara Valley Drain (MNVD) [30]. The Manchar Lake territory gets mean yearly precipitation of 4.43 inches while lake dissipation midpoints are 96 inches [30].

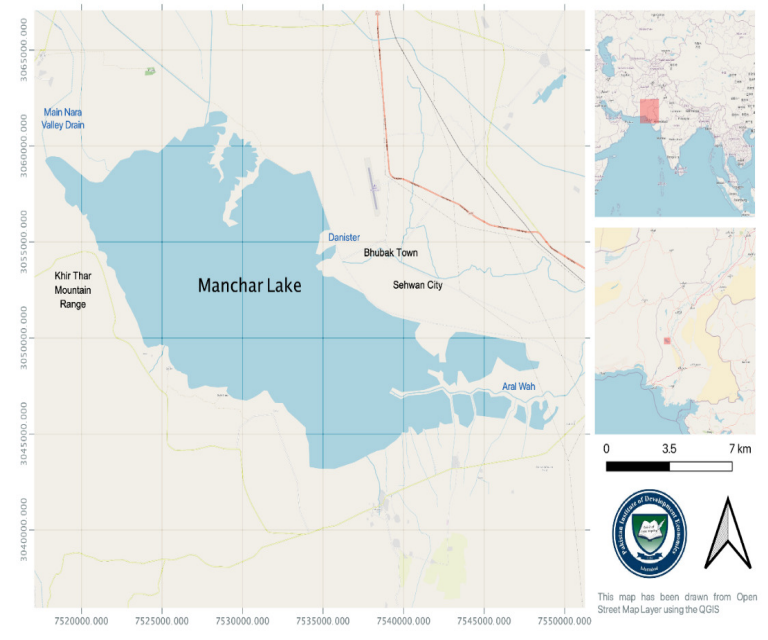

Fig 1: Map of the Study Area (The Manchar Lake)

\subsection{Socio-Economic Characters of Fishers}

The fishers have large household sizes, the reason behind is the joint family system which is very common in rural areas of Sindh (Pakistan Bureau of Statistics 2008). Fig. 2 shows the composition of the households. The fishers' households tend to be large; the average family size consists of 13 members. Traditional families in Sindh are extended, it may have many advantages such as physical support, coherence, psychological support, and stability and shared poverty particularly in hard times.

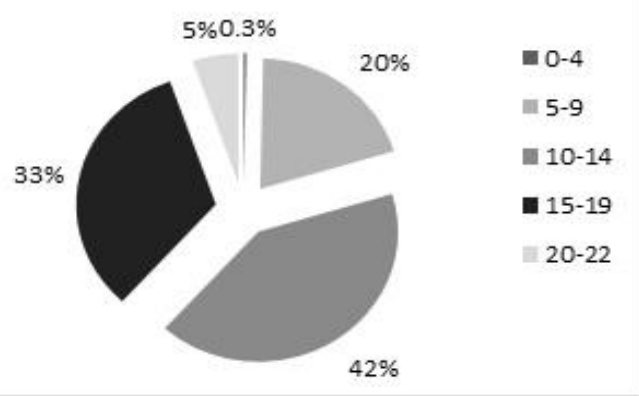

Fig 2: Family Size

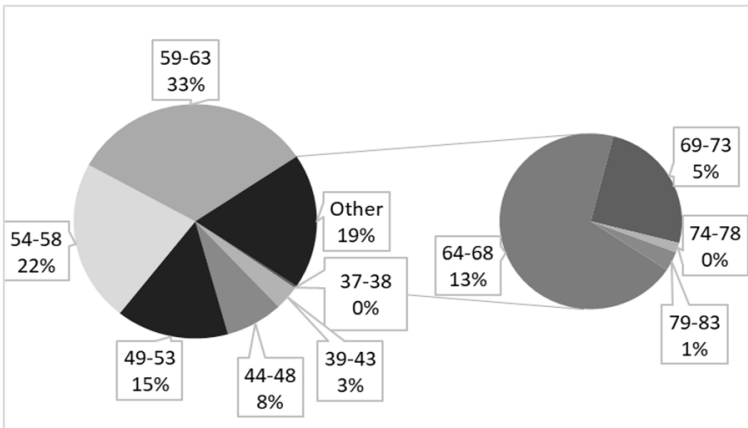

Fig 3: Age Profile of the Respondents

Fig 3 shows the frequency distribution of the respondent's age. Many fishers were old, and the mean age was almost 57 years exhibiting considerably their experience with the change and memory of the old times. It was observed during the survey that most of the fishers shifted to other professions after 1996 - a year since then the lake has received no freshwater from Indus River System. As a result, it has since then failed to tolerate the toxicity arising from the untreated industrial affluent discharged into the lake through Main Nara Valley Drain and ceased to support any major livelihood activity.

As formal education is not necessary to be a fisher thing. Fig. 4 shows most fishers never attained school. The reason for lack of education could be the lack of 
schools as there are only a few educational facilities in the Bubak region.

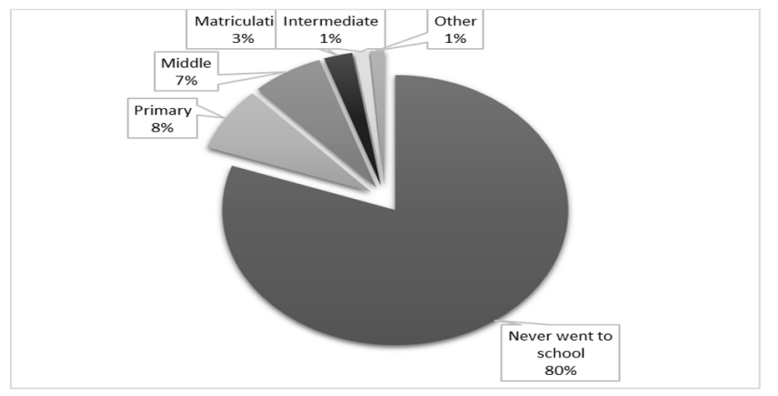

Fig 4: Educational Profile of the Respondents

Before switching to other jobs, their main occupation was fishing. There are five main occupations in which fishers are currently engaged namely, government job, private job, own business, daily wager, and farmer (Fig 5). However, fishers are very less educated most of them never went to school, so half of them are engaged in the daily wager. Many engage with shops or own small tea hotel/Dhaba. In cities, small businesses and daily wager opportunities are comparatively higher than other jobs.

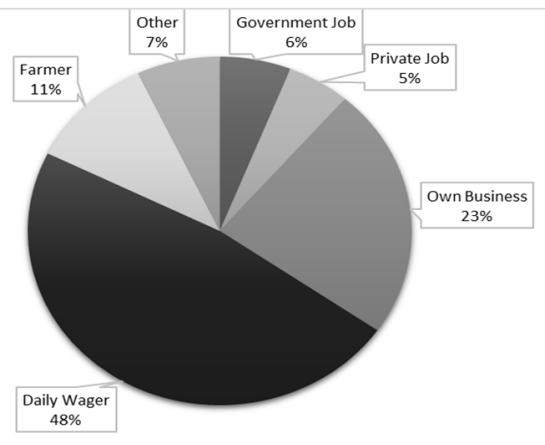

Fig 5: Occupational Profile of the Respondents

\subsection{Changes in Fishers' Capital and Costs}

Ever since the nature of fishers' job and job availability prospects has changed, they have had very poor access to non-fishing jobs. However, the neighboring cities provide a few low paying job opportunities. Results reveal statistically significant $(\mathrm{t}$ test at 0.05 level) differences in the average income, with their current earning are lesser than what they were earning while fishing on the Manchar Lake (Fig $6)$.

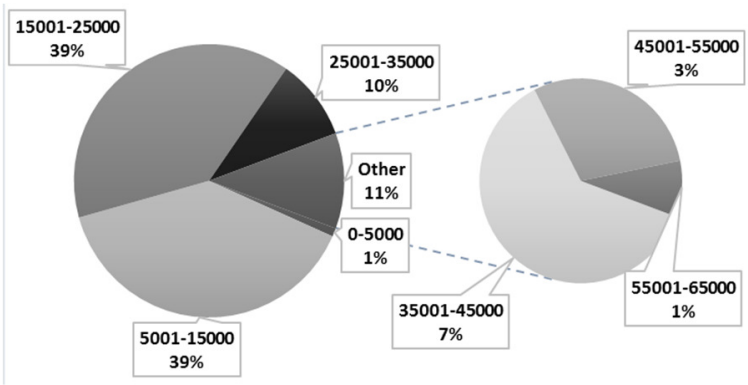

Fig 6: Income Profile of the Respondents

In the start, most fishers had to travel several hours to get to work, with average one side commuting distance could be about 7 kilometers. This compelled many to migrate to cities and other nearby town where there were alternate livelihood opportunities. Fig. 7 shows that currently at their new places the fishers enjoy better access to market, roads, and public services.

On average every worker spends 8 hours at work in Pakistan and every worker give a large share of their efforts and adult lives in work, so work is significantly related to job quality. As depicted in Fig 7b, the job quality indicators (job security, job safety, income security, labor requirements, and social prestige) capture farmers perceptions on different aspects of current job compared to when they were fishers. Results reveal that more than two-thirds of fishers are strongly dissatisfied with the quality of their current job quality in terms of income security (reliable income) because many are engaged as daily wager.

The same goes with job security and labor intensiveness of current jobs resulting in their dissatisfaction with what they are doing at the present. Majority seems to be satisfied with job safety (injuries and health hazards) their current jobs involve lesser risk of injury risk or other perceived aspects of occupational health.

Job commuting distance is generally seen as imposing cost and has significant effects on livelihood. However, distance can be measured in different ways such as in this study it is measured in terms of kilometers, monetary cost, and time spent on daily commute. Fig. 8 show that before when they were primarily fishers at Manchar Lake they were bearing lesser commuting cost than at the present. Because 
most of the fishers were living on the boats or by the side of the lake so they did not have to travel that far to earn their livelihoods.

Rural livelihood considerably depends on primary natural factors of production e.g., land and water. In many cases, e.g., [27], it has been observed that people tend to develop an attachment to place by romanticizing their surroundings including landscape, clean air, and community life. The same goes to the Manchar lake which is seen as valuable all in terms of cultural heritage, historical symbol in the stories and memories of local community, a place of eternal beauty and soothe and community cohesion (Fig 9). Whether fishers are likely to switch back to fishing in Manchar Lake or not but their attachment with lake remains the same in their memory.

Descriptive analysis of WTSB in Fig 9 shows that willingness to switch back to fishing in Manchar Lake is extremely high if the old benefits (Traditional fishing, aesthetic value, spiritual values, and cultural values) or both (old and new) benefits are provided as compared to the new benefits (boating, hoteling, sports fishing, and swimming).
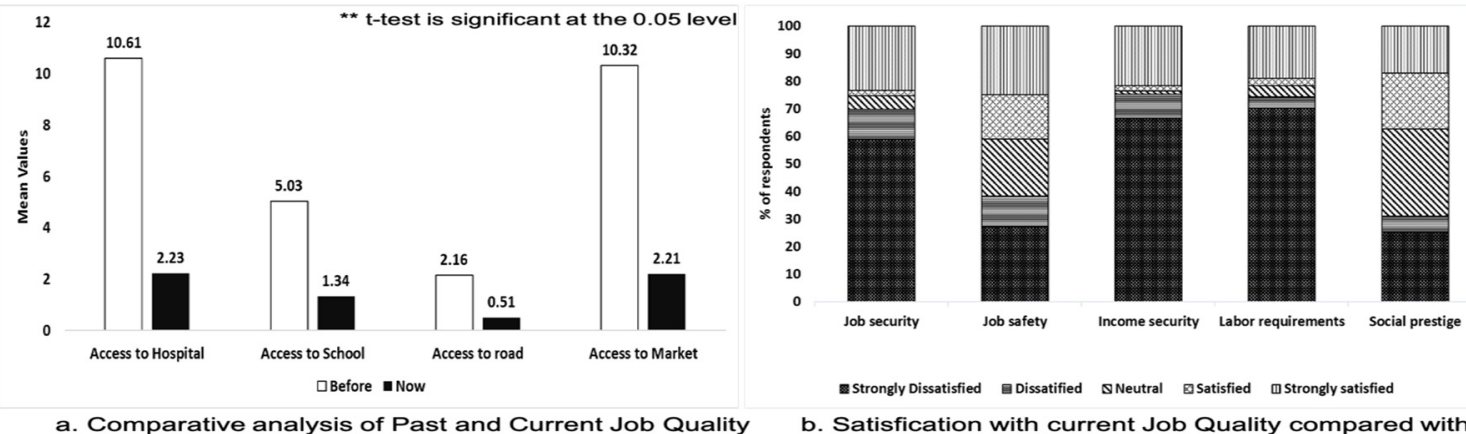

Fig 7: Analysis of Past and Current Job Quality

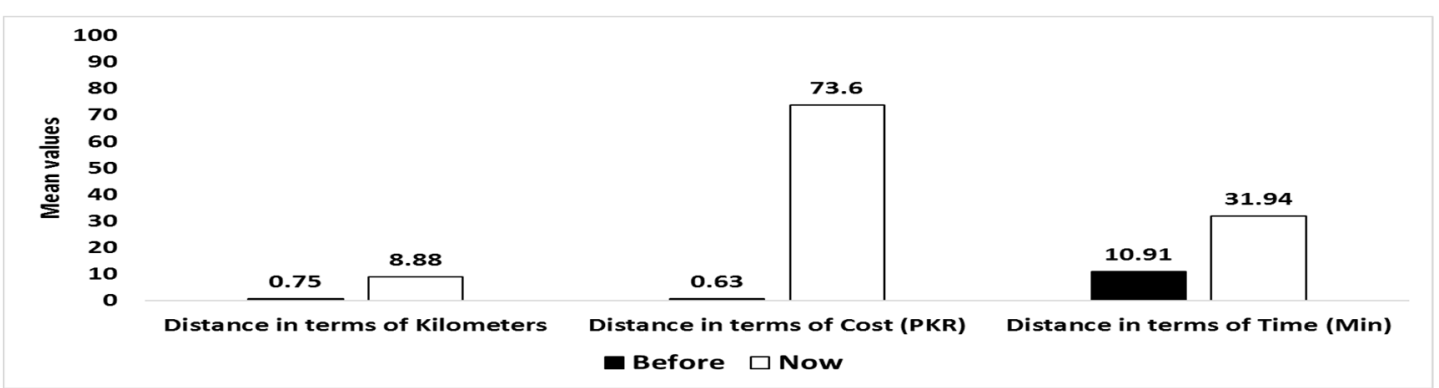

Fig 8: Workplace and House Commuting
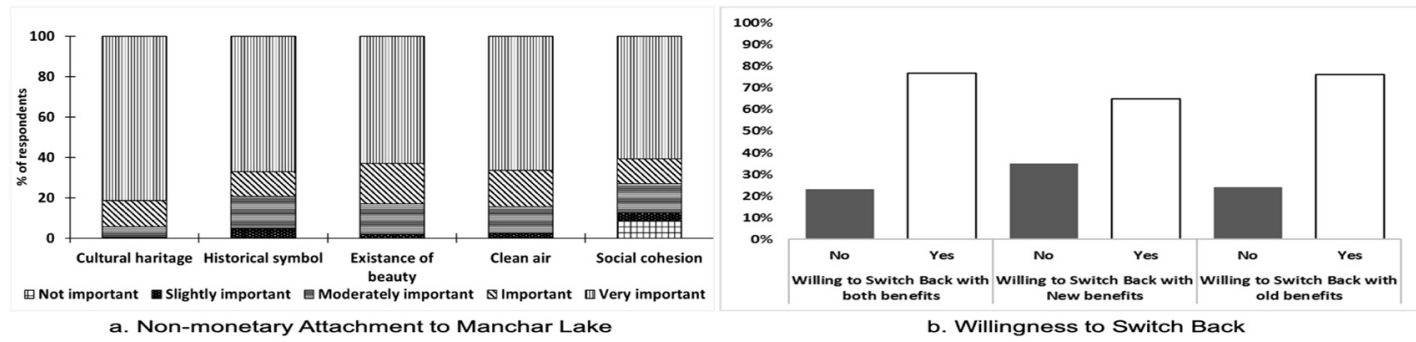

Fig 9: Attachment to Manchar and Willingness to Switch Back

\subsection{Regression Analysis}

In the context of descriptive analysis presented above, it is important to see what factors determine the erstwhile fishers WTSB to the hypothetically resorted Manchar Lake and play their socio-ecological role in full functioning of this ecosystem. Table. 2 shows the 
regression results of willingness to switch back to fishing in Manchar Lake with old benefits (Traditional fishing, aesthetic value, spiritual values, and cultural values), new benefits (tourism), and both benefits (old benefits and new benefits). Regression model for old benefits shows that education in years, migration time, partially migrated, facilities differential and total cost have statistically significant impact on willingness to switch back to fishing in Manchar Lake. While household size, age, age square, skill level, job quality, and attachment to Manchar Lake have statistically insignificant impact on WTSB.

Further, results show that fishers with higher educational attainments are less willing to switch back to fishing in Manchar Lake. Table. 2 shows that with an increase in one year of education reduce $4 \%$ probability of fishers to switch back to fishing in Manchar Lake, if the old benefits are provided. From the perspective of migration, the result indicates that migration time has negative relationship with willingness to switch back which means those fishers who migrated early to nearby town are less likely to switch back to fishing in Manchar Lake if only the old are guaranteed. While partially migrated variable has positive relationship with willingness to switch back so those fishers who partially migrated are more willing to switch back to fishing in Manchar Lake if the old benefits are guaranteed. Further, the result shows total cost (sum of opportunity cost and travel cost) has a positive relationship with willingness to switch back so by increasing in one thousand rupees in their total cost there is $30 \%$ probability of fishers likely to switch back to fishing in Manchar Lake if the old benefits are guaranteed.

If a new stream of benefits (essentially tourism related) is guaranteed, regression results in Table. 2 show that willingness to switch back is subject to the respondent's education, migration time, and total cost. While household size, age, age square, skill level, job quality, partially migrated, attachment to Manchar Lake and difference of facilities are statistically insignificant and do not impact WTSB under the guarantee of new benefits. Specifically, with an increase in one year of education reduce the probability of fishers by $4 \%$. While migration time has negative relationship, which means those fishers who migrated early to nearby town are less likely to switch back to fishing in Manchar Lake under the guarantee of new benefits. Table. 2 shows that the total cost associated with current job has a positive relationship with the willingness to switch back. The result shows that by increasing in one thousand rupees in their total cos, there are $13 \%$ chances of fishers' willingness to switch back to fishing in Manchar Lake under the guarantee of new benefits.

\begin{tabular}{|l|c|c|c|c|c|c|}
\hline \multirow{3}{*}{ Variables } & \multicolumn{7}{|c|}{ Table 2: Logit Model Result } \\
\cline { 2 - 7 } & Old benefits & New benefits (Tourism) & Old + New benefits \\
\cline { 2 - 7 } & Coeff. & ME & Coeff. & ME & Coeff & ME \\
\hline HH size & 0.0862 & 0.0130 & 0.1023 & 0.0226 & $-0.2163^{* *}$ & -0.0182 \\
\hline Age & 0.1448 & 0.0218 & -0.1428 & -0.0316 & -0.3384 & -0.0284 \\
\hline Age $^{2}$ & -0.0009 & -0.0001 & 0.0001 & 0.0001 & 0.0046 & 0.0004 \\
\hline Skill & -0.1936 & -0.0292 & -0.2100 & -0.0464 & 0.2843 & 0.0239 \\
\hline Education & $-0.3310^{* *}$ & -0.0499 & $-0.1833^{* *}$ & -0.0405 & 0.1853 & .0156 \\
\hline Job quality & -0.0687 & -0.0104 & 0.3595 & 0.0795 & $-1.2345^{* * *}$ & -0.1038 \\
\hline Migration Time & $-0.4300^{* * *}$ & -0.0649 & $-0.3167^{* * *}$ & -0.0700 & $-0.3143^{* * *}$ & -0.0264 \\
\hline Partially Migrated & $4.7585^{* * *}$ & 0.6122 & 0.5069 & 0.1102 & $-1.4370^{* *}$ & -0.1374 \\
\hline Attachment to Manchar & 0.5657 & 0.0854 & 0.2362 & 0.0522 & -0.1723 & -0.0145 \\
\hline Facilities & $-0.2650^{* *}$ & -0.0400 & -0.1177 & -0.0260 & -0.1290 & -0.0108 \\
\hline Total cost & $1.9964^{* * *}$ & 0.3012 & $0.6075^{* *}$ & 0.1343 & $1.2900^{*}$ & 0.1084 \\
\hline
\end{tabular}

Notes:

- $\quad$ ME is the abbreviation for Marginal Effects 
While in the case of both old + new benefits, regression results indicate that WTSB to Manchar Lake has a statistically significant negative relationship with household size such that increasing 1 member of household size reduces the chances of return to Manchar lake by $1 \%$. It is unusual and our observations couldn't capture the cause behind this result, but probable reason may be the fact that moving back of larger families may be logistically difficult than that of the smaller families. However, age, age square, skill, education in years, attachment to Manchar Lake, and difference of facilities are statistically insignificant. Table. 2 also suggests that migration time has negative relationship which means those fishers who migrated early to nearby towns are less willing to switch back to fishing in Manchar Lake even under the guarantee of both benefit streams. While partially migrated has a negative relationship with willingness to switch back to fishing in Manchar Lake and it has statistically significant impact on willingness to switch back to fishing in Manchar Lake under the guarantee of both benefit streams.

While total cost (sum of opportunity cost and travel cost) has statistically significant impact on willingness to switch back to fishing in Manchar Lake. Total cost (sum of opportunity cost and travel cost) has a positive relationship with the willingness to switch back. The result shows that an increase in one thousand rupees in their total cost, chances to return increase $10 \%$ chances under the guarantee of both benefit streams.

\section{DISCUSSION AND CONCLUSIONS}

Freshwater fishing is one of the oldest and circumglobally carried out livelihood activity [31]. Besides being an important recreational activity, fishing satisfies a significant portion of global nutritional needs. It is particularly important for supplying nutrients such as protein, essential fats to the poorest and rural residents [32], [33]. While recreational and commercial fisheries have attracted significant attention, the fishing activities of the poor are often neglected due to economic bias considering them as 'backward, informal, and minor financial exercises [34].
Resultantly freshwaters which inherently pro-poor [35] and contribute to sustain vulnerable livelihoods [36] are unable to attract required policy attention and are left at the whim of circumstances. This may cause their ecological degradation due to misuse as a sink for industrial and domestic pollutants and wastewater without much consideration livelihood loss of the poor who already lives along the margins of society.

However, thanks to the global environmental movement, the ecological importance of such environs is rising and efforts for their restoration are undergoing. However, a socio-ecological perspective on lake restoration suggests that symbiotic humanenvironment interaction is the fundamental character of any well-functioning ecosystem and neither human nor ecosystem can sustain in isolation from each other [37].

Manchar Lake and its ecological degradation exemplify one of such outcomes of ignorant policies but due to increasing awareness of policymakers and environmentalist groups, it one of the candidates for being Pakistan's first ecological lake restoration project [38, 39]. In this context, one may wonder would ecological restoration also translates into the restoration of socio-economic benefits that the lake used to provide before undergoing severe degradation. We brought this understanding not only to bring policy-relevant insights but also to inform the broader body on social and institutional dimensions of ecological restoration in general and that of the lake.

The regression results for switching back to old benefits show that education (years), migration time, partial migration, difference of facilities, and total cost of coming back are statistically significant. The results show that fishers with higher education are less likely to switch back to Manchar Lake. With an increase in one year of education, there is $4 \%$ reduction in the households' chances to switch back under the guarantee of old benefits.' From the migration perspective too, the result indicates that migration time has a negative relationship with WTSB which means that the earlier a fisher migrated the less likely their family would be willing to WTSB under this scheme. Partial or recent migration has a positive relationship to switch back which means those households who 
partially migrated would be more WTSB under the guarantee of traditional benefit stream.

In case of new benefits (tourism), the regression results of WTSB to fishing show that the education years, migration time, and total cost have statistically significant impact on willingness to switch back to fishing. In the case of new benefits (tourism), results show that fishers with higher education are less likely to switch back to fishing. The migration time too has a negative relationship which means those fishing households who migrated early to nearby towns are less likely to switch back to fishing even if tourism is restored. While in the case of both benefits (old benefits and new benefits), the regression results indicate that willingness to switch back to fishing in Manchar Lake if both benefits (old benefits and new benefits) are provided. The results show that migration time has a negative relationship which means those fishers who migrated early to nearby towns are less willing to switch back to fishing in any situation.

While the ecological argument may still suggest the restoration of Manchar Lake, the social argument is tricky particularly when relating to those who have done well from switching. Thus, there may be many who will be WTSB, one cannot assume that every erstwhile fisher will do this. However, as literature from elsewhere shows, one may consider that with the replenished fish stock, financial and social advantages would attract many nearby residents [40]. A brand new tourism industry and/or development of recreational fisheries also seems one possibility for cases like Manchar [41] and can be evaluated for increasing the value of restoration investments. Ecosystems which adequately support local livelihoods may get better stewardship than those solely serving environmental purposes [42]. This suggest that engaging a wider array of local actors in the lake rehabilitation efforts may trigger local interest in maintaining the health of lake ecosystem and long-term sustainability.

This can also be supported by the state of rural poverty in Sindh triggering local fishing ventures in the lake. The research elsewhere suggests that rural areas no more characterize single occupation families and that rural poor had been constantly looking for opportunities to enhance their livelihoods through diversifying their occupations [43 - 45].

As a cautionary note, one should realize that the results we obtained through this study are based on hypothetical scenarios. While such a technique is largely effective in bringing a priori understanding of the success of planned projects and initiatives, those exposed to such hypothetical situations must be aware of the technological plausibility of the proposal. In our case, one of the reasons that emerged from the field observation and discussion was that fishers were not much confident that a lake like Machar can even be restored, let alone offer a set of old and benefits that we hypothesized. This clearly shows that restoration involving only geo-engineers may not work.

Research elsewhere suggest that restoration works well where it is initiated by local community groups, local people, or their involvement in activities like revegetation, reproduction of hydrology, pest management, weed control, and local species reintroductions [46]. The achievement of restoration plans can be connected to having a brief arrangement of activity with clear objectives, quantifiable goals, sensible administration activities, and a versatile observing convention suited to the specific site necessities [47]. Restoration of contaminated ecological system is a tedious, expensive process that requires a long-term responsibility by those groups involved and an idea that soliciting local stakeholders' support in advance may justify the cost of restoration besides maximizing the overall success of the initiatives.

\section{REFERENCES}

[1] Stevenson J., "Ecological assessments with algae: a review and synthesis", Journal of Phycology, Vol. 50, No. 3, pp. 437-461, 2014.

[2] Seppelt R., Dormann C. F., Eppink F. V, Lautenbach S., Schmidt S., "A quantitative review of ecosystem service studies: approaches, shortcomings and the road ahead", Journal of Applied Ecology, vol. 48, no. 3, pp. 630-636, 2011.

[3] Ostrom E., Governing the Commons: The Evolution of Institutions for Collective Action, 
New York, USA: Cambridge University Press, 1990.

[4] Junk W. J., Shuqing A., Finlayson C., Gopal B., Kvet J., Mitchell S.A., Mitsch W.J., Robarts R.D., "Current state of knowledge regarding the world's wetlands and their future under global climate change: a synthesis", Aquatic Sciences, Vol. 75, No. 1, pp. 151-167, 2013.

[5] Davidson N. C., "How much wetland has the world lost? Long-term and recent trends in global wetland area", Marine and Fresh Water Research, Vol. 65, No. 10, pp. 934-941, 2014.

[6] Desta H., Lemma B., Albert G., and Stellmacher T., "Degradation of Lake Ziway, Ethiopia: A study of the environmental perceptions of school students", Lakes and Reservoirs Research and Management, Vol. 20, No. 4, pp. 243-255, 2015.

[7] Jeppesen E., Søndergaard M., Liu Z., "Lake Restoration and Management in a Climate Change Perspective: An Introduction", Multidisciplinary Digital Publishing Institute, 2017.

[8] W. L. Network, "Why Lake?,” 2004.

[9] Nindi J. S., "Changing livelihoods and the environment along Lake Nyasa, Tanzania," African Study Monograms, Suppl. 2007.

[10] Okpara U. T., Stringer L. C., Dougill A. J., "Lake drying and livelihood dynamics in Lake Chad: Unravelling the mechanisms, contexts and responses", Ambio, Vol. 45, No. 7, pp. 781-795, 2016.

[11] Phillips G., Bramwell A., Pitt J., Stansfield J., Perrow M., "Practical application of 25 years' research into the management of shallow lakes," Hydrobiologia, Vol. 395, pp. 61-76, 1999.

[12] Council N. R., Restoration of aquatic ecosystems: science, technology, and public policy, National Academies Press, 1992.

[13] Adler R. W., Landman J. C., Cameron D. M., The clean water act 20 years later, Island Press, 1993.

[14] Akele T., "The practice and challenges of lake management in Ethiopia-the case of lake Koka", M.Sc. Thesis, Department of Urban and Rural Development, Swedish University of Agricultural Sciences, Uppsala, Sweden, 2011.

[15] Minns C. K., Kelso J. R. M., Randall R. G., "Detecting the response of fish to habitat alterations in freshwater ecosystems", Canadian Journal of Fisheries and Aquatic Sciences, Vol. 53, No. S1, pp. 403-414, 1996.

[16] Allen C.D., Savage M., Falk D.A., Suckling K.F., Swetnam T.W., Schulke T., Stacey P.B., Morgan P., Hoffman M., Klingel J.T., "Ecological restoration of southwestern ponderosa pine ecosystems: a broad perspective", Ecological Applications, Vol. 12, No. 5, pp. 1418-1433, 2002.

[17] Memon J. A., Thapa G. B., "The Indus irrigation system, natural resources, and community occupational quality in the delta region of Pakistan", Environmental Management, Vol. 47, No. 2, pp. 173-187, 2011.

[18] Kozar R., Galang E., Alip A., Sedhain J., Subramanian S., Saito O., "Multi-level networks for sustainability solutions: the case of the International Partnership for the Satoyama Initiative", Current Opinion in Environmental Sustainability, Vol. 39, pp. 123-134, 2019.

[19] Barribeau P. et al., "Survey research. writing@ csu", Department of English, Colorado State University", 2005.

[20] Miah A. Q., Applied statistics for social and management sciences. Bangkok: Springer, 2016.

[21] CBS, "District Level Indicators of Nepal for Monitoring Overall Development (Based on selected socio-economic indicators)", Central Bureau of Statistics, Kathmandu, Nepal., 2003.

[22] Sharma P., "Impacts of conflict induced displacement in the livelihoods of internally displaced persons (IDPS) in nepal," School of Environment Resources and Development, Asian Institute of Technology, Thailand, 2009.

[23] Mahdi G., Shivakoti P., Schmidt-Vogt D., "Livelihood Change and Livelihood Sustainability in the Uplands of Lembang 
Subwatershed, West Sumatra, Indonesia, in a Changing Natural Resource Management Context", Environmental Management, Vol. 43, No. 1, p. 84, 2008.

[24] Holden S. T., Shiferaw B., "Poverty and land degradation: Peasants' willingness to pay to sustain land productivity", Natural Resources Management in African Agriculture: Understing and Improving Current Practices, 2002.

[25] Bryman A., Social Research Methods. Oxford University Press, 2016.

[26] Memon J. A., Thapa G. B., "The Indus irrigation system, natural resources, and community occupational quality in the delta region of Pakistan", Environmental Management, Vol. 47, No. 2, pp. 173-187, 2011.

[27] Memon J. A., Jogezai G., Hussain A., Alizai M. Q., Baloch M.A., "Rehabilitating Traditional Irrigation Systems: Assessing Popular Support for Karez Rehabilitation in Balochistan, Pakistan", Human Ecology, Vol. 45, No. 2, pp. 265-275, 2017.

[28] A. Ressurreição et al., "Different cultures, different values: The role of cultural variation in public's WTP for marine species conservation", Biological Conservation, Vol. 145, No. 1, pp. 148-159, 2012.

[29] Arain M. B., Kazi T. G., Jamali M. K., Jalbani N., Afridi H. I., Shah A., "Total dissolved and bioavailable elements in water and sediment samples and their accumulation in Oreochromis mossambicus of polluted Manchar Lake", Chemosphere, Vol. 70, No. 10, pp. 1845-1856, 2008.

[30] Zehra S. M., "Time series models of the electrical conductivity measured at the Manchar Lake in Pakistan", Masters Thesis, Department of Mechanical Engineering, University of Texas at Austin, 2010.

[31] Pringle C. M., "Exploring how disturbance is transmitted upstream: going against the flow", Journal of the North American Benthological Society, Vol. 16, No. 2, pp. 425-438, 1997.

[32] Youn S.-J. et al., "Inland capture fishery contributions to global food security and threats to their future", Global Food Security, Vol. 3, No. 3-4, pp. 142-148, 2014.

[33] Yin F., Zhang Z., "Survey of Chaohu Lake eutrophication research", Journal of Lake Science, Vol. 15, No. 4, pp. 377-384, 2003.

[34] Platteau J., "The dynamics of fisheries development in developing countries: a general overview", Development and Change, Vol. 20, No. 4, pp. 565-597, 1989.

[35] Sneddon C., Fox C., "Power, development, and institutional change: Participatory governance in the lower Mekong basin", World Development, Vol. 35, No. 12, pp. 2161-2181, 2007.

[36] BNP, "Big Number Program: Intermediate Report", 2009.

[37] Poteete A. R., Ostrom E., "Fifteen Years of Empirical Research on Collective Action in Natural Resource Management: Struggling to Build Large-N Databases Based on Qualitative Research", World Development, Vol. 36, No. 1, pp. 176-195, 2008.

[38] The Express Tribune, "Restoration of Manchar Lake demanded", The Express Tribune, Karachi, 23-Mar-2018.

[39] Khan M. H., "Who cares about the demise of Manchar Lake," DAWN, Karachi, 09-Aug2018.

[40] Hutchings J. A., Walters C., Haedrich R. L., "Is scientific inquiry incompatible with government information control?", Canadian Journal of Fisheries and Aquatic Sciences, Vol. 54, No. 5, pp. 1198-1210, 1997.

[41] Cooke S. J., Cowx I. G., "The role of recreational fishing in global fish crises", Bioscience, Vol. 54, No. 9, pp. 857-859, 2004.

[42] Memon J. A., Thapa G. B., "Explaining the de facto open access of public property commons: Insights from the Indus Delta mangroves", Environmental Science Policy, Vol. 66, pp. 151-159, 2016.

[43] Welcomme R. L. et al., "Inland capture fisheries", Philosophical Transactions of the Royal Society B: Biological Sciences, Vol. 365, No. 1554, pp. 2881-2896, 2010.

[44] Pittaluga F. et al., "Poverty profile of riverine communities of southern Lake Volta", 2003. 
[45] Ellis F., "Household strategies and rural livelihood diversification", The Journal of Development Studies, Vol. 35, No. 1, pp. 138, 1998.

[46] Clewell A. F., Aronson J., Ecological Restoration: Principles, Values, and Structure of an Emerging Profession, Island Press, 2013.

[47] Ehrenfeld J. G., "Defining the limits of restoration: the need for realistic goals", Restor. Ecol., Vol. 8, No. 1, pp. 2-9, 2000. 